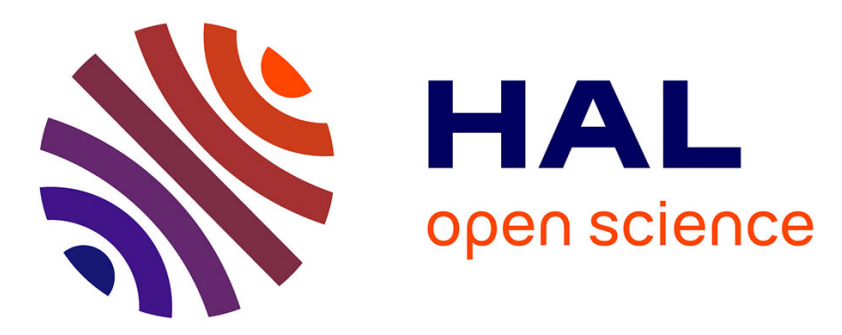

\title{
Globalization and Mental Health
}

Nick Manning, Vikram Patel

\section{To cite this version:}

Nick Manning, Vikram Patel. Globalization and Mental Health. Global Social Policy, 2008, 8 (3), pp.299-300. 10.1177/1468018108095625 . hal-00571823

\section{HAL Id: hal-00571823 \\ https://hal.science/hal-00571823}

Submitted on 1 Mar 2011

HAL is a multi-disciplinary open access archive for the deposit and dissemination of scientific research documents, whether they are published or not. The documents may come from teaching and research institutions in France or abroad, or from public or private research centers.
L'archive ouverte pluridisciplinaire HAL, est destinée au dépôt et à la diffusion de documents scientifiques de niveau recherche, publiés ou non, émanant des établissements d'enseignement et de recherche français ou étrangers, des laboratoires publics ou privés. 


\title{
Globalization and Mental Health
}

\section{A Special Issue of Global Social Policy}

\author{
NICK MANNING \\ University of Nottingham, $U K$ \\ VIKRAM PATEL \\ London School of Hygiene and Tropical Medicine, India
}

Globalization has significant consequences for mental health. Social processes associated with globalization, such as employment pressures, migration (including migration of health human resources), poverty, culture, and social change can be risk or protective factors for disorders such as suicide, substance abuse, antisocial behaviour, anxiety, and depression. Globalization also has effects on the provision of health and social care to those with mental health problems, whether or not these have been generated by globalization.

It has recently been estimated by the British economist, Lord Richard Layard (2005), that mental health problems cost the economy more than poverty (http://www.strategy.gov.uk/downloads/files/mh_layard.pdf), and yet it is an issue that is seldom included in the range of problems linked to globalization. In the recent first issue of a new journal, Globalization and Health (2005) (http://www.globalizationandhealth.com), there was not a single reference to mental health issues.

However, this low profile is beginning to change. The general case for a step change in policies for mental health was set out by the World Health Organization (WHO) in 2002 in its Mental Health Global Action Programme (mhGAP) (http://www.who.int/mental_health/media/en/265.pdf). In September 2006, the UK Institute of Psychiatry's third international mental health conference took place, on the theme 'People on the Move' (http://www.iop.kcl.ac.uk/ iopweb/virtual/?path=/international/conference/). The large majority of plenary and parallel session speakers were from low and middle income countries, with significant representation from sub-Saharan Africa, the Middle East, Latin America, and South Asia. On 3 September 2007, Vikram Patel, in 
parallel to this special edition of GSP, launched a special series on a global call for a mental health strategy for LCDs in The Lancet (see The Lancet, 2007 (370): 859-77 at http://www. thelancet.com/journals/lancet/article/PIIS0140 673607 612380/abstract). This call for a global mental health strategy was launched by Professor Jeff Sachs, the WHO, and a number of senior international figures in health policy.

The current special issue of GSP, edited by Nick Manning and Vikram Patel, adds to this growing debate.

BIOGRAPHICAL NOTES

NICK MANNING is Professor of Social Policy and Sociology at the School of Sociology and Social Policy, University of Nottingham. Please address correspondence to Nick Manning, School of Sociology and Social Policy, University of Nottingham, University Park, Nottingham, NG7 2RD, UK. [email: nick.manning@ nottingham.ac.uk]

VIKRAM PATEL is Professor and Director of the Institute of Mental Health and Wellcome Trust Senior Clinical Research Fellow in Tropical Medicine at the London School of Hygiene \& Tropical Medicine, based in Goa, India. Please address correspondence to Vikram Patel, London School of Hygiene \& Tropical Medicine, Sangath Centre, Porvorim, Goa 403521, India. [email: vikram.patel@lshtm.ac.uk] 